\title{
Changes in Maritime Transportation
}

E-commerce and B2B applications, which have been developing rapidly around the world, have caused changes in purchasing behaviors of customers. These customers are experiencing an era in which they are directly reaching remote sellers and buying the goods they demand by removing intermediary companies from the market. In this era, e-commerce platforms those bring customers and sellers together and consolidate their demand for transportation have become such a big power that they have started to take over national and international freight transport. Foremost among those e-commerce platforms are Alibaba, Fedex and Amazon. The largest transportation fleets are competing intensely in order to take a share of the transportation of e-commerce platform companies. The agreement between Alibaba and CMA CGM may be shown as the best example for this. This change, changing of the captain in the logistic chain in other words, is the shift of center of the power in the international transport towards e-commerce platforms. The competitive advantage of these platforms is to be able to begin managing all transportation systems effectively by digitizing the trade. In short, success of digitized platforms is to transform digitalization into commoditization by creating change in trade.

This rapid transformation is expected to lead major changes by influencing the maritime transportation which is conducted in traditional methods. First of these changes is to increase efficiency by accelerating the maritime transport which is relatively slow against the speed of e-commerce. Second one are the efforts to unman the transport operations, carried out under shadow of human errors, as much as possible. Presently, change has entered into the process of abandoning the traditional maritime that is currently being preserved and leaving its place to digital platforms and systems.

The first target of the change process is identified as "ports and ship operations", which are the weakest links of the maritime transport chain. The change in these operations is the transformation of traditional methods to digitized systems in order to ensure efficiency and effectiveness. As a method, it is proposed to establish platforms to perform the functions of the land decision support and operation centers as in the air transportation. E-navigation concept has already been offered as an application of digitized platform for maritime transportation. The most important and crucial issue for completing the transformation of marine transportation is national and international regulations. The first question that comes to mind is "When will this change happen?" Answer to this question is the time when change supporters want to win the controversy between those who need to change and those who are resistant to change.

The change in ship operations is the transformation of conventional ship operations into a system in which digital platforms consisting of deck, engine and bridge devices that can work and communicate in harmony among themselves which can be accessed and communicated 
remotely. The change process has already begun and it is now a matter of time that ship operations are becoming easily monitored from land. The first stage is the establishment of platforms that will be installed on the coast and reach and communicate with shipboard devices. This stage is called "Coast Decision Support Center". Decision and responsibility still lies with the ship captain. The role of ship master has changed. Ship master, in operations carried out by smart devices, has undergone a change of mission in which he can follow the data provided him and he can intervene when appropriate. The completion date of the first stage is predicted to be 2025 .

Digitization will be completed (e-navigation) at the second stage. When national and international regulations related to the change begin to be implemented, the name of the platform on the coast will change to "Coast Operation Center". The development of unmanned ships has been completed and a change of mission has occurred in which ship operations are managed by programmed decisions and in which artificial intelligence is monitored by data sent to the coast. The completion date of the second stage is predicted to be 2035 .

As a result, taking positions for adapting to and facing up to the change and being aware that the change will always win have became the priority subjects of survival at this stage.

Editor

Prof. Dr. Selçuk NAS 


\section{Deniz Ulaştırmasında Değişimler}

Dünyada büyük bir hızla gelişen e-ticaret ve B2B uygulamaları müşterilerin satın alma davranışlarında değişiklikler yaratmıştır. Müşteriler aracı şirketleri ortadan kaldırarak doğrudan uzak satıcılara ulaşıp, talep ettiği malları doğrudan satın aldığı bir çağ yaşanmaktadır. Bu çağda müşteri ile satıcıyı buluşturan ve taşıtma taleplerini konsolide eden e-ticaret platformları öyle bir büyük güç haline gelmiştirki, ulusal ve uluslararası yük taşımacılığını da ele geçirmeye başlamıştır. Bu platformların başında, Alibaba, Fedex ve Amazon gelmektedir. En büyük ulaştırma filoları ise e-ticaret platformlarının taşıma kapasitelerinden pay kapabilmek amacıyla yoğun bir rekabet içine girmiștir. Buna en iyi örnek Alibaba ile CMA CGM arasındaki anlaşma gösterilebilir.Buradaki değişim, lojistik zincirindeki "kaptanın" değișmesi, uluslararası taşımalarda güç merkezinin e-ticaret platformlarına doğru kaymasıdır. Bu platformların rekabetçi üstünlügü, ticareti sayısallaştırarak tüm ulaştırma sistemlerini efektif ve etkin bir şekilde yönetmeye başlamasıdır. Kısacası, sayısal platformların ticarette değişim yaratarak dijitalleşmeyi metalaştırmayadönüştürmeyi başarmalarıdır.

Bu hızlı dönüşümün geleneksel usullerde yapılmakta olan deniz ulaştırmasını etkilemesi ve büyük değişimlere yol açması beklenmektedir. Bu değişimlerin başında, e-ticaretin hızı karşısında çok yavaş kalan deniz ulaştırmasının hızlandırılarak verimliliğinin arttırılması gelmektedir. İkinci olarak ise insan hatalarının gölgesinde yapılan bir ulaştırma operasyonunun mümkün olduğunca insansızlaştırma çabaları gelmektedir. Değişim, şu anda korunmaya çalıșılan geleneksel denizciliği dönüşüme uğratarak ortadan kaldırmaya, yerini ise sayısal platformlara ve sistemlere bırakma sürecine girmiştir.

Değişim sürecinin ilk hedefi; deniz ulaştırma zincirinin en zayıf halkaları olan liman ve gemi operasyonları olarak belirlenmiștir. Bu operasyonlardaki değișim, verimliliğin ve etkinliğin sağlanması amacıyla geleneksel usullerin sayısallaştırılmış sistemlere dönüşmesidir. Yöntem olarak ise hava taşımacılığında olduğu gibi, yer karar destek ve operasyon merkezlerinin görevlerini yapacak platformların kurulması önerilmektedir. E-navigasyon kavramı, deniz ulaştırması için sayısallaştırılmış bir platform uygulaması olarak sunulmuştur. Deniz ulaştırmasındaki değişimin tamamlanması için en önemli ve kritik konu, ulusal ve uluslararası düzenlemelerdir. Akla gelen ilk soru, "bu değişim ne zaman olacak?" sorusudur. Bunun cevabı, değișim ihtiyacı olanlar ile değişime direnenler arasındaki çekişmeyi, değişim yanlılarının ne zaman kazanmayı isteyecekleridir.

Gemi operasyonlarında yaşanacak değişim; geleneksel gemi operasyonlarının, kendi arasında uyumlu çalışabilen, konuşabilen güverte, makine ve köprüüstü aygıtlarının oluşturduğu sayısal platformların, uzaktan erişilebildiği, uzaktan konuşulabildiği bir sisteme dönüşmesidir. Değişim süreci hali hazırda başlamış olup, gemi operasyonlarının karadan da rahatlıkla izlenebilen bir hale dönüşmesi artık an meselesidir. İlk aşamada; sahilde kurulacak olan ve gemiye ulaşarak gemi aygitları ile konuşabilecek platformların 
kurulma aşamasıdır. Bu aşamaya "Sahil Karar Destek Merkezi" adı verilmektedir. Karar ve sorumluluk hala gemi kaptanındadır. Gemi kaptanının rolü değişmiştir. Gemi kaptanı, akıllı aygıtların yürüttüğü operasyonlarda, kendisine sunulan verileri takip ettiği ve yeri gediğinde de müdahale edebildiği bir görev değişimi geçirmiştir. İlk aşamanın tamamlanma tarihi için 2025 yılı öngörülmektedir.

İkinci aşamada sayısallaştırma tamamlanacaktır (e-navigation). Değişim ile ilgili ulusal ve uluslararası düzenlemeler uygulanmaya başlandığında sahildeki platformun adı "Sahil Operasyon Merkezi" olarak değişecektir. Artık gemilerde insansızlaştırma tamamlanmıș, gemideki operasyonları programlanabilir kararlar ile yöneten, yapay zekâların sahile gönderdiği veriler ile takip edildiği bir görev değişimi gerçekleşmiştir. İkinci aşamanın tamamlanma tarihi için 2035 yllı öngörülmektedir.

Sonuç olarak bu aşamada, değişime uyum sağlamak için pozisyon almak ve değişim ile yüzleşmek, değişimin her zaman kazanacağını bilmek, hayatta kalmanın öncelikli konuları haline gelmiştir.

Editör

Prof. Dr. Selçuk NAS 